\title{
Hubungan Antara Rasa Komunitas dengan Motivasi Kerja Pengurus Subak
}

\author{
Yande Prayoga dan Yohanes Kartika Herdiyanto \\ Program Studi Psikologi, Fakultas Kedokteran, Universitas Udayana \\ yandeprayoga@gmail.com
}

\begin{abstract}
Abstrak
Subak merupakan organisasi irigasi tradisional yang telah diakui sebagai warisan dunia. Namun, pengakuan tersebut seharusnya dibarengi dengan penyelesaian permasalahan nyata yang terjadi pada subak itu sendiri, yang semestinya memerlukan perhatian khusus. Salah satu hal yang bisa dilakukanyaitu meningkatkan rasa komunitas pengurus subak agar mempunyai motivasi kerja dalam mengelola subaknya. Berdasarkan hal tersebut, penelitian ini bertujuan untuk mengetahui hubungan antara rasa komunitas dengan motivasi kerja pengurus subak.

Penelitian ini menggunakan metode penelitian kuantitatif dengan teknik korelasi product moment. Jumlah responden dalam penelitian ini yaitu 58 orang yang diambil dengan menggunakan teknik cluster sampling. Pengukuran penelitian ini menggunakan skala rasa komunitas yang dimodifikasi dari McMillan dan Chavis (1986) dengan 34 aitem (nilai koefisien cronbach's alpha sebesar 0,898 dan nilai koefisien validitas $=0,314$ hingga 0,637 ) dan skala motivasi kerja yang dimodifikasi dari Dewi (2008) dengan 27 aitem(nilai koefisiesn cronbach's alpha sebesar 0,885 dan nilai koefisien validitas $=0,308$ hingga 0,617 ), dengan koefisien korelasi $+0,556$. Pelanggaran kontrak psikologis tidak memiliki hubungan dengan intensi turnover.

Hasil penelitian ini diperoleh bahwa nilai korelasi antara variabel rasa komunitas dengan variabel motivasi kerja sebesar 0,696 dengan probabilitas sebesar $0,000(p<0,05)$ yang menjelaskan bahwa H0 ditolak dan Ha penelitian diterima. Angka tersebut menunjukkan bahwa terdapat hubungan yang positif dan signifikan antara rasa komunitas dengan motivasi kerja pengurus subak. Selain itu, diperoleh nilai koefisien determinasi sebesar 0,484 yang menunjukkan sumbangan relatif variabel rasa komunitas terhadap motivasi kerja sebesar 48,4\%. Hasil ini sejalan dengan teori yang diungkapkan Hughey, dkk. (1999) bahwa rasa komunitas akan mendorong hasil yang berarti pada organisasi
\end{abstract}

Kata kunci: rasa komunitas, motivasi kerja dan pengurus subak

\begin{abstract}
Subak is a traditional organization of irrigation that have been known as one of the world heritages. However, it recognition should be done with the way to accomplish real problems that happened in itself, which supposed to have particular concerns. One thing that could be done is increasing the sense of community among subak's committee so that they will have job motivation to run subak. Based on that fact, the aim of this study is to know the relationship between sense of community with job motivation among subak's committee.

Methods used in this study was quantitative research methods with product-moment correlation to do data analysis. The subjects were choosen with cluster sampling technique for the total number of 58 subjects. The measurements used were sense of community modified scales from McMillan and Chavis (1986) with 34 items (cronbach's alpha is 0,898 and validity coefficient ranged from $0,314-0,637$ ) and job motivation modified scales from Dewi (2008) with 27 items (cronbach's alpha is 0,885 and validity coefficient ranged from $0,308-0,617$ ).

The result of this study indicates that the correlation values of sense of community and job motivation is 0,696 with 0,00 probability $(\mathrm{p}<0,05)$. It explained that Ho rejected and Ha accepted. Those values indicates that there are positive and significant relationship between sense of community and job motivation of subak's comittee. In addition, determinant coefficient result is 0,484 that pointed the relative contribution among sense of community with job motivation is $48,4 \%$. This result is similiar with the theory from Hughey, et.al. (1999) which reveals that sense of community will encouraged maningful results for organization.
\end{abstract}

Keywords: sense of community, job motivation, work motivation and subak's committee 


\section{Y. PRAYOGA DAN Y. K. HERDIYANTO}

\section{LATAR BELAKANG}

Subak telah diakui sebagai warisan budaya dunia oleh United Nations Educational, Scientific and Cultural Organization (UNESCO) (Farhan, 2012). Pengakuan UNESCO terhadap subak tidak terlepas dari konsep THKyang melandasi subak yang mampu mengantisipasi permasalahan yang timbul pada sistem irigasi pada umumnya dan kemungkinan kekurangan air khususnya pada musim kemarau (Farhan, 2012). Namun, dibalik pengakuan tersebut, subak juga memiliki tantangan untuk menjaga keberadaannya. Tantangan tersebut artinya menjaga sistem organisasi masyarakat subak dengan menyatukan nilai budaya, tetapi tetap menjaga tata guna lahan, kualitas air, dan debit air (Zakiya, 2012). Dengan melakukan sistem pengaturan air sesuai konsep THK maka akan memungkinkan tercapainya keberhasilan dalam sistem irigasi air (Windia, 2000). Melihat pengakuan dari beberapa pihak yang telah dipaparkan di atas, subak seharusnya dapat menjadi organisasi yang mengelola sistem irigasi dengan baik, serta dapat menghadapi tantangan yang ada kedepannya.

Berdasarkan data Dinas Kebudayaan Provinsi Bali (2012), jumlah subak yang berada di Provinsi Bali pada tahun 1993, antara lain: Kabupaten Jembrana: 94 Subak, Tabanan: 362 subak, Klungkung: 43 subak, Gianyar: 257 subak, Bangli: 51 subak, Karangasem: 131 subak, dan Buleleng: 289 subak. Kemudian, peneliti mencoba melihat perkembangan jumlah subak pada tahun 2011. Pada tahun 2011, jumlah subak di Provinsi Bali dari data inventarisasi Dinas Kebudayaan Provinsi Bali (2012), antara lain: Jembrana: 83 Subak, Tabanan: 348 subak, Klungkung: 46 subak, Gianyar: 465 subak, Bangli: 56 subak, Karangasem: 140 subak, dan Buleleng: 296 subak. Berdasarkan paparan diatas, peneliti menyimpulkan bahwa sebagian besar kabupaten yang berada di Bali mengalami peningkatan jumlah subak, namun hal tersebut tidak terjadi pada 2 kabupaten: Kabupaten Jembrana dan Tabanan. Dua kabupaten tersebut justru mengalami penurunan pada jumlah subak. Hal ini juga diikuti dengan penurunan luas sawah yang dialiri air oleh subak di 2 kabupaten tersebut. Sesuai data dari Badan Pusat Statistik (2010), luas lahan sawah yang dialiri air oleh subak di 2 kabupaten (Hassanudin, 2012). Berdasarkan paparan di atas, sebagian jumlah subak di sebagian besar kabupaten memang mengalami peningkatan, namun masih ada 2 kabupaten yang mengalami penurunan jumlah subak: Jembrana dan Tabanan, subak yang telah diakui oleh dunia perlu menjadi perhatian khusus dalam menjaga keberadaannya. Apabila hal tersebut tidak diperhatikan, keberadaan subak akan semakin berkurang di 2 kabupaten tersebut.

Sebagai organisasi irigasi tradisional, subak merupakan suatu wadah atau organisasi para petani yang memiliki tekad dan semangat yang tinggi untuk bekerja sama secara gotong royong dalam upaya mendapatkan air dengan tujuan memproduksi tanaman pangan khususnya padi dan palawija (Sutawan, 2008). Dengan kata lain, anggota subak mempunyai kebutuhan yang sama yaitu kepentingan akan air untuk mengairi sawah mereka. Sedangkan, pengelolaan subak itu sendiri merupakan tugas dari pengurus subak.

Menurut Sirtha (2008), tugas dari pengurus subak yaitu melakukan pengaturan dan pengelolaan air yang merata dan adil kepada para anggotanya. Selain itu, pengurus subak juga bertanggung jawab mendamaikan perselisihan yang berkaitan dengan subak (Sirtha, 2008). Dengan kata lain, pengurus subak yang melakukan tugasnya dengan baik, maka akan mengoptimalkan pengelolaan subak itu sendiri. Menurut Sutawan (2008), pengurus subak sendiri juga mempunyai hakhak, antara lain: Hak untuk mendapatkan imbalan yang biasanya ditentukan pada hasil keputusan rapat; Mengatur perencanaan pola tanam, jadwal tanam, dan pembagian air; Mengkoordinasikan kegiatan subak; dan mendelegasikan tugas kepada pengurus subak lainnya.

Dalam mengelola organisasi subak, pengurus subak pasti akan menemukan permasalahan dalam proses mengelola subak (Donder, 2008). Sirtha (2008) mengemukakan suatu kasus bahwa anggota subak mengajukan tuntutan oleh karena ketidak adilan pengurus subak dalam melaksanakan tugas. Tugas yang dimaksud adalah tugas dalam mengatur pembagian air secara adil. Hal ini mengakibatnya munculnya kasus kecemburuan sosial mengenai debit air yang diperoleh anggota subak. Selain itu, Sirtha (2008) mengemukakan bahwa terdapat kasus lain berupa perbedaan pola tanam yang dilakukan anggota subak. Perbedaan pola tanam yang dimaksud adalah petani tidak melaksanakan waktu penanaman padi sesuai yang telah ditentukan pada hasil rapat. Apabila petani tidak melakukan pola tanam secara serentak, maka sawahnya akan menjadi sumber hama. Implikasinya yaitu hama akan menginggapi sawah lain yang berdekatan atau yang sedang melakukan penanaman padi. Hal ini mengakibatkan gagal panen yang diperoleh sejumlah petani. Hal yang disayangkan, kesalahan ini terjadi berulang kali. Sehingga, para anggota subak mengajukan tuntutan kepada pengurus subak terkait permasalahan yang harus segera ditangani.

Idealnya, pengurus subak seharusnya memiliki rasa memiliki, tanggung jawab, komitmen yang tinggi untuk merancang sistem yang lebih baik dalam pengelolaan subak. Sayangnya, fakta-fakta sesuai paparan diatas mengatakan bahwa pengurus subak masih melakukan kelalaian dalam melaksanakan tugas pengaturan air dan membuat para anggota subak juga ikut bertindak menangani permasalahan, yang seharusnya menjadi tugas pengurus subak.

Berdasarkan hasil wawancara terhadap beberapa kelihan subak yang berada di Kecamatan Pekutatan, sebagian besar pengurus subak mempunyai peran ganda yaitu sebagai pengurus banjar atau desa dan juga merupakan seorang ayah 


\section{Y. PRAYOGA DAN Y. K. HERDIYANTO}

yang harus mencari nafkah untuk keluarganya. Dengan peranperan yang dijalani tersebut bukanlah hal yang mudah. Sehingga, beberapa pengurus subak merasa "terpaksa" untuk menjalani tugasnya. Selain itu, beberapa pengurus subak hanya sekedar menjadi pengurus subak tanpa diimbangi melaksanakan tugasnya. Sehingga, beberapa pengurus subak merasakan ketidak adilan dan merasakan memikul kerja yang berat tanpa dukungan kerja dari pengurus lainnya.

Selain itu, kesulitan dana yang kerap kali menjadi permasalahan perbedaan pola tanam terjadi di subaknya. Kesulitan dana yang dimaksud adalah kesulitan dana dalam hal membeli bibit padi. Dari data dinas Kebudayaan dan Pertanian Provinsi Bali (2012), ternyata setiap subak di Bali telah diberikan dana bantuan untuk dana operasional subak. Selain itu, Pemerintah Kabupaten Jembrana (2012), juga sudah memberikan bantuan berupa dana bantuan operasional dan 1 buah sepeda motor kepada masing-masing subak yang berada di Kabupaten Jembrana. Hal ini diberikan untuk membantu persoalan dana dan mempercepat kerja dari pengurus subak, bahkan pada salah satu subak yang berada di Kecamatan Pekutatan memiliki dana operasional yang memadai dan mampu memberikan pinjaman kepada anggota subak yang kekurangan dana dalam pembelian bibit maupun pupuk. Dana yang diperoleh subak di dapatkan dari iuran anggota-anggota subak dan bantuan operasional dari pemerintah.

Apabila seorang pengurus subak mempunyai perasaan memiliki dalam mengelola subaknya tersebut. Pengurus subak seharusnya melakukan kerja yang optimal dalam mengelola subaknya itu sendiri. Sehingga, tidak timbul perasaan "terpaksa" dan perasaan memikul kerja yang berat pada beberapa pengurus.

Perasaan memiliki pengurus subak dalam mengelola subak sesuai dengan definisi rasa komunitas yang diungkapkan McMillan dan Chavis (1986). Rasa komunitas (sense of community) adalah perasaan memiliki akan komunitas dan perasaan berharga dalam suatu komunitas, sehingga timbul keyakinan untuk bersama dalam komunitas (McMillan dan Chavis, 1986). Seorang yang memiliki rasa komunitas yang baik akan mendorong individu untuk bekerja lebih baik.

Dugaan dalam penelitian yaitu seorang pengurus subak yang memiliki rasa komunitas yang tinggi, maka akan bertanggung jawab dalam melakukan pengaturan air serta mengatur permasalahan pola tanam, yang seharusnya bisa ditangani secara bijak agar tidak terjadi berulang kali. Dengan kata lain, pengurus subakyang memiliki rasa komunitas yang tinggi, maka meningkatkan partisipasinya dalam tugas maupun penyelesaian masalah yang terjadi di subak tersebut atau mempunyai motivasi kerja yang tinggi.

Menurut Sutrisna (2011), tenaga kerja yang berkualitas akan menghasilkan suatu hasil kerja yang optimal atau sesuai dengan target yang seharusnya dikerjakan. Manusia sebagai tenaga kerja merupakan sumber daya yang penting bagi organisasi. Sumber daya manusia juga mempunyai berbagai macam kebutuhan yang ingin dipenuhinya. Keinginan seseorang untuk memenuhi kebutuhan inilah yang dapat memotivasi seseorang untuk melakukan sesuatu termasuk untuk melakukan pekerjaan atau bekerja.

Motivasi kerja sangat penting untuk ditumbuhkan dan terus ditingkatkan karena motivasi adalah sesuatu yang bersifat mendorong untuk terus bersemangat dalam bekerja (Handayani, 2010). Motivasi adalah suatu faktor yang mendorong seseorang untuk melakukan suatu aktivitas tertentu. Oleh karena itu, motivasi sering kali diartikan pula sebagai faktor pendorong perilaku seseorang (Priono, 2012). Menurut Sutrisno (2009), motivasi kerja dipengaruhi oleh beberapa faktor yang dapat dibedakan menjadi 2, yaitu: Faktor internal meliputi keinginan untuk hidup, keinginan untuk dapat memiliki, keinginan untuk memperoleh penghargaan, keinginan untuk memperoleh pengakuan dan keinginan untuk berkuasa; dan faktor eksternal meliputi kondisi lingkungan kerja, kompensasi yang memadai, pengawasan yang baik, adanya jaminan pekerjaan, adanya penghargaan atas prestasi, peraturan yang fleksibel, status dan tangung jawab.

Untuk mengoptimalisasi pengelolaan subak, salah satu cara yang bisa dilakukan yaitu dengan meningkatkan mutu dari sumber daya manusianya. Hal penting yang perlu dilakukan menjaga keberadaan subak yaitu menjaga komitmen para pengurus subak untuk tetap berkonsentrasi mengelola para anggotanya (Balipost, 2010). Hal yang sependapat juga diungkapkan oleh Sutrisna (2011), antisipasi yang bisa dilakukan dalam melestarikan sistem subak di Bali adalah dengan melakukan pendekatan-pendekatan seperti membuat koperasi tani, lembaga perkreditan subak, dan lain-lain yang ada pada sistem subak, meringankan beban ekonomi anggota subak dan yang terakhir dengan meningkatkan motivasi kerja dari pengurus subak.

Motivasi kerja dalam suatu organisasi merupakan hal penting dikarenakan motivasi kerja berhubungan dengan kinerja seseorang. Hasil penelitian Komara (2008) menunjukkan bahwa terdapat hubungan yang signifikan antara motivasi kerja dengan kinerja seseorang, sehingga motivasi kerja yang tinggi merupakan suatu hal yang penting untuk dilakukan suatu penelitian. Dalam penelitian yang dilakukan Komara (2008), dalam meningkatkan motivasi kerja dapat dilakukan dengan melihat beberapa faktor motivasi kerja dan faktor motivasi intrinsik menjadi suatu hal yang penting dalam meningkatkan motivasi kerja tersebut.

Berdasarkan paparan kasus di atas, dapat disimpulkan bahwa subak merupakan aset penting bagi masyarakat Bali yang perlu kita jaga dan lestarikan. Dugaan dalam penelitian yaitu seorang pengurus subak yang memiliki rasa komunitas 
yang tinggi, maka akan bertanggung jawab dalam melakukan pengaturan air serta mengatur permasalahan pola tanam, yang seharusnya bisa ditangani secara bijak agar tidak terjadi kesalahan berulang kali. Dengan kata lain, pengurus subak yang memiliki rasa komunitas yang tinggi, maka akan meningkatkan partisipasinya dalam tugas maupun penyelesaian masalah yang terjadi di subak tersebut serta akan mempunyai motivasi kerja yang tinggi dalam menjalankan tugasnya. Oleh karena itu, peneliti tertarik untuk melakukan penelitian untuk mengetahui hubungan antara rasa komunitas dengan motivasi kerja pengurus subak.

\section{METODE}

\section{Variabel dan definisi operasional}

Variabel penelitian adalah sesuatu yang ditetapkan oleh peneliti untuk diperoleh informasi dari sebuah penelitian dan ditarik kesimpulannya (Sugiyono, 2011). Variabel independent (variabel bebas) adalah variabel yang diduga mempengaruhi atau yang menjadi penyebab perubahan dari variabel tergantung dan variabel dependent (variabel tergantung) merupakan variabel yang diduga dipengaruhi atau yang menjadi akibat, adanya variabel bebas (Sugiyono, 2009). Variabel bebas pada penelitian ini yaitu rasa komunitas dan variabel tergantung pada penelitian ini yaitu motivasi kerja.

Definisi operasional variabel rasa komunitas adalah perasaan yang membuat anggota untuk memiliki, merasa dirinya penting terhadap anggota yang lain maupun kelompok sehingga timbul keyakinan akan kebersamaan untuk mencapai sebuah komitmen dalam komunitas (McMillan dan Chavis, 1986). Rasa komunitas pada penelitian ini ditunjukkan dari 4 aspek, yaitu keanggotaan, pengaruh, pemenuhan kebutuhan dan berbagai secara emosional.

Definisi operasional variabel motivasi kerja adalah daya pendorong yang mengakibatkan pengurus subak mengerahkan kemampuannya dalam bentuk keterampilan, tenaga dan waktu untuk menyelenggarakan berbagai kegiatan yang menjadi tanggung jawab dan kewajiban dalam mencapai tujuan organisasi yang telah ditentukan (Siagan, 2004). Motivasi kerja dalam penelitian ini ditunjukkan dari 3 aspek, yaitu bersikap positif, memiliki dorongan untuk mencapai tujuan karir, dan memiliki harapan untuk membuahkan hasil yang sebaik-baiknya.

\section{Responden}

Populasi adalah keseluruhan dari objek maupun subjek penelitian yang memiliki kualitas dan karakteristik tertentu yang ditetapkan oleh peneliti untuk dipelajari dan kemudian ditarik kesimpulannya. Populasi dalam penelitian ini yaitu pengurus subak yang berada di Kecamatan Pekutatan, Kabupaten Jembrana, Bali yang sesuai dengan kriteria sampel penelitian ini.
Alasan peneliti menggunakan Kecamatan Pekutatan karena keberadaan subak di kecamatan tersebut lebih banyak yang aktif dibandingkan kecamatan lain yang berada di Kabupaten Jembrana, sehingga mempermudah peneliti dalam pengambilan data. Selain itu, keterbatasan yang dimiliki peneliti dalam hal tenaga, dana dan waktu, maka peneliti memutuskan tidak mengikut sertakan seluruh individu yang berada di Kabupaten Jembrana. Atas dasar ini, peneliti melakukan pengambilan sampel pengurus subak yang berada di Kecamatan Pekutatan, Kabupaten Jembrana. Sampel adalah bagian dari jumlah dan karakteristik yang dimiliki oleh populasi (Sugiyono, 2012). Karakteristik populasi dalam penelitian sebagai berikut:

1. Subjek menjadi salah satu pengurus subak yang berada di Kecamatan Pekutatan (Kelian subak (pekaseh), wakil kelian, sekretaris (Penyarikan/Juru Tulis), bendahara (Petengen/Juru Raksa), pembantu umum (Saya/Juru arah/Juru tibak/kasioman).

2. Subjek masih menjadi pengurus subak hingga dengan tahun 2013 di Kecamatan Pekutatan, Kabupaten Jembrana, Provinsi Bali.

Berdasarkan paparan di atas, sampel dalam penelitian ini adalah subjek penelitian yang sesuai dengan kriteriakriteria dari populasi penelitian ini.

Penelitian ini menggunakan metode pengambilan sampel probability sampling dengan teknik cluster sampling. Menurut Sugiyono (2012), metode pengambilan data ini digunakan untuk menentukan sampel yang sangat luas.

\section{Alat ukur}

Variabel rasa komunitas diukur menggunakan skala rasa komunitas dimodifikasi berdasarkan skala Sense of Community Index ( SCI ) yang dibuat oleh McMillan dan Chavis (1986). Skala dalam penelitian ini menggunakan skala interval, yang disajikan dalam bentuk pernyataan-pernyataan sebanyak 36 aitem. Aitem-aitem pada skala ini mengungkap 4 aspek dari rasa komunitas yang dikemukakan oleh McMillan dan Chavis (1986).

Variabel motivasi kerja diukur menggunakan skala motivasi kerja yang dimodifikasi berdasarkan skala motivasi kerja yang dibuat oleh Dewi (2008). Skala dalam penelitian ini menggunakan skala interval, yang disajikan dalam bentuk pernyataan- pernyataan sebanyak 30 aitem. Aitem- aitem pada skala ini mengungkap 3 aspek dari motivasi kerja yang disampaikan oleh Dewi (2008).

Teknik yang digunakan dalam menentukan nilai respon dalam skala penelitian ini mengacu pada teknik skala likert (Silalahi, 2009). Menurut Silalahi (2009), teknik skala likert digunakan untuk mengukur sikap, pendapat dan persepsi 


\section{Y. PRAYOGA DAN Y. K. HERDIYANTO}

seseorang atau sekelompok orang terhadap suatu hal. Teknik penskalaan likert yang digunakan dalam penelitian ini hanya menggunakan empat alternatif jawaban, yaitu sangat setuju (SS) , setuju (S), tidak setuju (TS), dan sangat tidak setuju (STS). Skor yang diberikan pada skala ini bergerak dari 1 sampai 4, yaitu untuk skor aitem favorable: $S S=4, S=3$, TS $=2$ dan $\mathrm{STS}=1$. Sedangkan, untuk skor aitem unfavorable: $\mathrm{SS}=1, \mathrm{~S}=2$, TS $=3$ dan $\mathrm{STS}=4$.

Pengujian validitas penelitian ini menggunakan uji validitas tampak dan uji validitas konstruk dengan melihat nilai koefisien validitas rix menunjukkan nilai lebih besar dari $0,30(>0,30)$ atau tidak. Apabila nilai koefisien validitas rix menunjukkan lebih besar dari 0,30 maka data dapat dikatakan valid. Sedangkan, penelitian ini menggunakan pendekatan konsistensi internal, yaitu pendekatan yang didasarkan pada data dan satu kali pengenaan satu bentuk alat ukur pada sekelompok subjek (single trial administration) (Azwar, 2000). Pengujian reliabilitas ditunjukkan pada nilai cronbach's alpha sebesar 0,6 atau tidak. Apabila nilai lebih besar 0,6 maka data dapat dikatakan reliabel.

\section{Metode pengumpulan data}

Metode pengambilan data dilakukan menggunakan 2 buah skala: rasa komunitas dan motivasi kerja. Penyebaran skala dilakukan dengan datang ke masing-masing rumah pengurus subak.

Penyebaran skala penelitian ini disesuaikan dengan prinsip etika dan kode etik psikologi APA (2002). Pertemuan pertama dengan responden diawali dengan memberikan salam dan memperkenalkan diri dengan menyampaikan tujuan kedatangan menemui responden. Setelah itu, diberikan kertas yang merupakan bagian pertama skala penelitian yaitu lembar penjelasan penelitian dan juga dijelaskan secara singkat tentang gambaran, tujuan dan manfaat pada penelitian kepada responden beserta keterlibatan responden dalam penelitian ini. Setelah responden paham dan mengatakan bersedia menjadi responden dalam penelitian ini, maka kami meminta responden untuk mengisi lembar kedua yaitu surat pernyataan kesediaan sebagai responden. Setelah itu, kami berdiskusi tentang pengisian bagian ketiga dan keempat yaitu skala rasa komunitas dan motivasi kerja yang berjumlah 76 item

\section{Teknik analisis data}

Setelah data terkumpul, kemudian dilakukan uji validitas dan reliabilitas. Hasil uji validitas diperoleh nilai koefisien validitas rix rasa komunitas bergerak dari 0,314 hingga 0,637 dan nilai koefisien validitas rix motivasi kerja bergerak hingga 0,308 hingga 0,617. Sedangkan, hasil uji reliabilitas diperoleh nilai Cronbach's Alpha rasa komunitas sebesar 0,898 dan nilai Cronbach's Alpha motivasi kerja sebesar 0,885 .

Data akan dianalisis menggunakan teknik korelasi product moment. Analisis data dilakukan secara komputasi dengan bantuan software statistical for social science (SPSS) versi 17.0 for windows. Namun, dilakukan terlebih dahulu uji asumsi data: uji normalitas dan linieritas.

Uji normalitas merupakan cara untuk mengetahui apakah data yang diperoleh dalam penelitian berdistribusi normal atau tidak (Sugiyono, 2012). Uji normalitas menggunakan teknik Kolmogorov-Smirnov Test. Apabila nilai signifikansi lebih besar dari 0,05 (>0,05), maka data yang diperoleh dapat dinyatakan memiliki distribusi yang normal (Priyatno, 2008).

Uji linieritas bertujuan untuk mengetahui apakah dua variabel mempunyai hubungan yang linier atau tidak secara signifikan yang menunjuk pada suatu garis sejajar atau tidak (Nurgiyantoro, Gunawan \& Marzuki, 2008). Apabila nilai p lebih besar dari 0,05 $(>0,05)$, maka hubungan antara kedua variabel tidak linier. Apabila nilai p lebih kecil dari 0,05 $(<0,05)$, maka dapat dinyatakan memiliki hubungan antara kedua variabel linier.

Dari uji asumsi data penelitian, data penelitian ini dapat dinyatakan normal dan linier. Kemudian, dilakukan teknik korelasi product moment yang dilakukan dengan melihat nilai signifikansi. Apabila nilai signifikansi kurang dari 0,05 $(<0,05)$ maka H0ᄀditolak dan Ha diterima sedangkan apabila nilai lebih dari $0,05(>0,05)$ maka $\mathrm{H} 0\urcorner$ diterima dan Ha ditolak.

\section{Hasil Penelitian}

Pelaksanaan pengambilan data dalam penelitian ini dimulai dari tanggal 14 April 2013 hingga 25 April 2013. Penyebaran skala selama pelaksanaan penelitian ini dapat terlaksana dengan baik dan seluruh sampel yang telah ditentukan bersedia menjadi responden dalam penelitian ini. Penyebaran skala penelitian ini disesuaikan dengan prinsip etika dan kode etik psikologi APA (2002).

Dari data yang diperoleh karakteristik responden: Frekuensi usia responden dan frekuensi pendidikan terakhir yang diuraikan sesuai tabel berikut:

Tabel 1

Frekuensi Usia Responden

\begin{tabular}{cll}
\hline Usia & Frekuensi & Persentase \\
$30-39$ & 15 & $25,86 \%$ \\
$40-49$ & 28 & $48,28 \%$ \\
$50-59$ & 13 & $22,41 \%$ \\
$60-64$ & 2 & 3,45 \\
\hline Jumlah & 58 & $100 \%$ \\
\hline
\end{tabular}


Berdasarkan tabel 1, dapat disimpulkan karakteristik usia responden berusia antara usia 30 hingga 64 tahun dan sebagian besar berusia antara 40 hingga 49 tahun.

Tabel 2

Frekuensi Pendidikan Terakhir

\begin{tabular}{cll}
\hline Pendidikan Terakhir & Frekuensi & Persentase \\
SD & 16 & $27,59 \%$ \\
SMP & 19 & $32,76 \%$ \\
SMA & 22 & $37,93 \%$ \\
S1 & 1 & $1,72 \%$ \\
\hline Jumlah & 58 & $100 \%$ \\
\hline
\end{tabular}

Berdasarkan tabel 2, dapat disimpulkan seluruh responden dalam penelitian ini memiliki riwayat pendidikan terakhir. Rentang pendidikan terakhir responden-responden dalam penelitian ini dimulai SD hingga S1. Selain itu, dapat disimpulkan bahwa sebagian besar responden memiliki karakteristik responden pendidikan terakhir yaitu kategori SMA yang berjumlah 22 orang.

Hasil uji normalitas dapat dilihat dari sebaran 2 skala dalam penelitian ini yang dijelaskan sesuai tabel berikut:

Tabel 3

Hasil Uji Normalitas

\begin{tabular}{lrr}
\hline & Rasa Komunitas & \multicolumn{1}{c}{ Motivasi Kerja } \\
\hline Kolmogorov-Smirnov Z & 0.904 & 0.667 \\
Asymp. Significant & 0.387 & 0.765 \\
\hline
\end{tabular}

Berdasarkan tabel 3, sebaran data pada variabel rasa komunitas dan motivasi kerja memiliki nilai signifikansi dengan probabilitas di atas 0,05 (p>0,05). Hal ini menunjukkan bahwa sebaran data pada variabel rasa komunitas dan motivasi kerja bersifat normal.

Hasil uji linearitas dalam penelitian ini diuraikan sesuai tabel berikut :

Tabel 4

Hasil Uji Linearitas

\begin{tabular}{lclll}
\hline & & & F & Signifikansi \\
\hline rasa & Between & (Combined) & 37.149 & .000 \\
komunitas * & Groups & Linearity & 552.283 & .000 \\
motivasi & & Deviation from & 19.385 & .000 \\
kerja & & Linearity & & \\
\hline
\end{tabular}

Berdasarkan table 4, diperoleh angka probabilitas lebih kecil dari 0,000 (<0,05). Angka ini menunjukkan hubungan antara skor variabel rasa komunitas dan motivasi kerja telah memenuhi syarat adanya garis sejajar atau linier.
Tabel 5

Hasil Uji Korelasi dan Hipotesis

\begin{tabular}{llrr}
\hline & & rasa komunitas & motivasi kerja \\
\hline rasa komunitas & Pearson & 1 & $.696^{* *}$ \\
& Correlation & & \\
& Sig. (1-tailed) & 58 & .000 \\
& $\mathrm{~N}$ & $.696^{* *}$ & 58 \\
\hline motivasi kerja & Pearson & & \\
& Correlation & .000 & 58 \\
& Sig. (1-tailed) & 58 & \\
& $\mathrm{~N}$ & & 58 \\
\hline
\end{tabular}

Hasil uji korelasi diuraikan sesuai tabel diatas:

Berdasarkan tabel 5, diperoleh nilai probabilitas (p) sebesar 0,000. Nilai tersebut mencerminkan $\mathrm{p}<0,05$ yang menunjukkan $\mathrm{H} 0$ ditolak dan Ha yang menyatakan bahwa terdapat hubungan positif antara rasa komunitas dengan motivasi kerja pengurus subak. Dalam analisis korelasi, terdapat suatu angka yang disebut dengan koefisien determinasi (r2) yang diperoleh dengan cara mengkuadratkan nilai koefisien $r(0,696)$, sehingga didapatkan hasil $r 2$ sebesar 0,484 . Koefisien determinasi ini menunjukkan besarnya peran atau sumbangan efektif yang dapat diberikan dari variabel bebas terhadap variabel tergantung (Sugiyono, 2012). Dalam penelitian ini, sumbangan relatif yang diberikan oleh variabel rasa komunitas terhadap motivasi kerja yaitu sebesar 48,4\%. dan selebihnya sebesar $51,6 \%$ dipengaruhi oleh faktor lain yang tidak diteliti dalam penelitian ini.

Hasil hubungan positif di atas dikuatkan oleh kategorisasi responden-responden penelitian dalam 5 kelompok (Azwar, 2010). Tujuan dari pengelompokan ini adalah untuk menempatkan subjek ke dalam kelompok yang terpisah secara berjenjang menurut kontinum berdasarkan atribut yang diukur (Azwar, 2000). Hasil Kategorisasi skala rasa komunitas akan dipaparkan sesuai dengan tabel sebagai berikut:

Tabel 6

Tabel Kategorisasi Subyek pada Skala Rasa Komunitas

\begin{tabular}{|c|c|c|c|}
\hline Skor & Kategorisasi & Subjek & Persentase \\
\hline $\mathrm{X} \leq(59,5)$ & Sangat Rendah & 0 & $0 \%$ \\
\hline$(59,5)<\mathrm{X} \leq(76,5)$ & Rendah & 0 & $0 \%$ \\
\hline$(76,5)<X \leq(93,5)$ & Sedang & 0 & $0 \%$ \\
\hline$(93,5)<X \leq(110,5)$ & Tinggi & 24 & $41,38 \%$ \\
\hline$(110,5)<\mathrm{X}$ & Sangat Tinggi & 34 & $58,62 \%$ \\
\hline \multicolumn{2}{|c|}{ Jumlah } & 58 & $100 \%$ \\
\hline
\end{tabular}

Berdasarkan tabel 6, 41,38\% responden atau sebanyak 24 orang responden memiliki rasa komunitas dalam kelompok tinggi dan 58,6\% responden sisanya atau sebanyak 34 orang responden memililki rasa komunitas dalam kelompok yang sangat tinggi. Sedangkan hasil kategorisasi skala motivasi kerja dijelaskan sesuai tabel berikut: 
Tabel 7

Kategorisasi Responden pada Skala Motivasi Kerja

\begin{tabular}{cccc}
\hline Skor & Kategorisasi & Subjek & Persentase \\
\hline $\mathrm{X} \leq(47)$ & Sangat Rendah & 0 & $0 \%$ \\
$(47)<\mathrm{X} \leq(60,75)$ & Rendah & 0 & $0 \%$ \\
$(60,75)<\mathrm{X} \leq(74,25)$ & Sedang & 5 orang & $8,62 \%$ \\
$(74,25)<\mathrm{X} \leq(94,5)$ & Tinggi & 38 orang & $65,52 \%$ \\
$(94,5)<\mathrm{X}$ & Sangat Tinggi & 15 orang & $25,86 \%$ \\
\hline Jumlah & & 58 orang & $100 \%$ \\
\hline
\end{tabular}

Berdasarkan tabel $7,8,62 \%$ responden yang berjumlah 5 orang responden memiliki motivasi kerja dalam kelompok sedang, $65,52 \%$ responden yang berjumlah 38 orang responden memililki motivasi kerja dalam kelompok yang tinggi dan $25,86 \%$ responden yang berjumlah 15 orang responden memililki motivasi kerja dalam kelompok yang sangat tinggi.

\section{PEMBAHASAN DAN KESIMPULAN}

Penelitian ini merupakan penelitian dengan metode kuantitatif dengan teknik analisis korelasi product moment dengan tujuan mengetahui hipotesis yang diajukan penelitian ini ditolak atau diterima. Berdasarkan hasil uji hipotesis tersebut diperoleh hasil koefisien $r$ antara variabel rasa komunitas dan variabel motivasi kerja sebesar (+) 0,696 dengan angka probabilitas (p) sebesar 0,000 atau kurang dari $0,05(<0,05)$.

Nilai yang keluar dari hasil uji hipotesis penelitian ini menunjukkan $\mathrm{H} 0$ ditolak dan $\mathrm{Ha}$ diterima. Hal ini menunjukkan terdapat hubungan antara variabel rasa komunitas dengan variabel motivasi kerja yang berkorelasi secara positif dan signifikan. Hubungan yang positif menunjukkan: Apabila terjadi peningkatan pada variabel rasa komunitas maka akan terjadi peningkatan pula pada variabel motivasi kerja dan begitu juga sebaliknya. Apabila terjadi penurunan pada rasa komunitas pengurus subak maka akan terjadi penurunan pula pada motivasi kerja pengurus subak.

Hasil ini mendukung asumsi penelitian ini bahwa rasa komunitas yang dimiliki pengurus subak akan meningkatkan motivasi kerja. Menurut McMilllan dan Chavis (1986), rasa komunitas pengurus subak terbentuk dari perasaan-perasaan yang dimiliki pengurus subak seperti perasaan yang nyaman, senang berbagi cerita karena kesamaan yang dimiliki pengurus subak dengan anggota lain dan ikatan yang kuat dari interaksi yang mereka lakukan. Semakin banyaknya interaksi telah yang dilakukan oleh para pengurus dengan pengurus ataupun anggota subak lainnya akan menjalin keakraban diantara para anggota dan pengurus. Hughey (1999) mengatakan rasa komunitas pengurus subak akan mendorong hasil yang berarti pada organisasi subak. Pengurus subak yang memiliki rasa komunitas akan menciptakan ritualnya sendiri dan kebiasaan bertukar pikiran. Rasa komunitas yang dimiliki pengurus akan membentuk kelekatan pengurus (McMillan, 1996). Dengan kelekatan inilah yang akan meningkatkan motivasi kerja pengurus subak (Arninda, 2012).

Dari hasil penelitian ini juga diperoleh nilai koefisien determinasi (r2) dengan mengkuadratkan nilai korelasi dari hasil uji hipotesis $(0,696)$ sehingga didapatkan hasil r2 sebesar 0,484 . Nilai koefisien determinasi ini menunjukkan besarnya peran atau sumbangan yang dapat diberikan dari variabel bebas terhadap variabel tergantung (Sugiyono, 2012). Dalam penelitian ini, sumbangan relatif dari variabel rasa komunitas terhadap variabel motivasi kerja sebesar 48,4\%. Sedangkan sumbangan lain terhadap variabel motivasi kerja sebesar $51,6 \%$, yang diperoleh dari faktor-faktor lainnya yaitu faktor luar diri individu seperti : kepemimpinan, kompensasi dan tempat kerja (Hamzah, 2011).

Selain itu, hasil penelitian ini juga menunjukkan tingkat rasa komunitas dan motivasi kerja yang dilakukan dengan melakukan kategorisasi dari skor yang diperoleh responden. Berdasarkan hasil kategorisasi tingkat rasa komunitas responden menunjukkan bahwa terdapat $41,38 \%$ dari sampel atau sebanyak 24 orang responden memiliki rasa komunitas dalam kelompok tinggi dan 58,6\% responden sisanya atau sebanyak 34 orang responden memililki rasa komunitas dalam kelompok yang sangat tinggi. Secara keseluruhan dapat disimpulkan bahwa sebagian besar responden atau 34 pengurus subak memiliki rasa komunitas dalam kategori yang sangat tinggi. Hasil ini dapat menunjukkan tinggi rendahnya rasa komunitas yang dijelaskan dengan definisi operasional rasa komunitas. Dengan kata lain, hasil ini menunjukkan bahwa perasaan memiliki pengurus subak akan kebersamaan demi mencapai komitmennya pada subak di Kecamatan Pekutatan lebih didominasi oleh rasa komunitas pengurus subak kategori sangat tinggi.

Sumbangan relatif sebesar $48,4 \%$ rasa komunitas terhadap motivasi kerja dan tingginya rasa komunitas berdasarkan kategorisasi yang diperoleh responden dapat dijelaskan dari manfaat yang diperoleh dari bab II: Tinjauan pustaka. Sumbangan tersebut menunjukkan bahwa pengurus subak dengan rasa komunitas akan membentuk kelekatan kepada komunitasnya dan memberikan pengaruh yang berarti dalam organsisasi. Bentuk pengaruh berarti itu berupa: proses mengelola organisasi, membangun hubungan dengan kelompok luar organisasi, memberi pengaruh terhadap persepsi individu dalam keikutsertaan dalam organisasi dengan serta bisa mempengaruhi masyarakat luas dan membentuk hubungan dengan orang-orang yang tidak mengenal satu sama lain dalam meningkatkan kualitas hidup.

Selain itu, berdasarkan hasil penelitian ini juga diperoleh kategorisasi tingkat motivasi kerja responden sebagai berikut: Terdapat $8,62 \%$ responden berada dalam kelompok sedang, 65,52\% responden berada dalam kelompok tinggi dan $25,86 \%$ responden berada dalam kelompok sangat 
tinggi. Berdasarkan tabel $17,8,62 \%$ responden yang berjumlah 5 orang responden memiliki motivasi kerja dalam kelompok sedang, $65,52 \%$ responden yang berjumlah 38 orang responden memililki motivasi kerja dalam kelompok yang tinggi dan $25,86 \%$ responden yang berjumlah 15 orang responden memililki motivasi kerja dalam kelompok yang sangat tinggi. Secara keseluruhan dapat disimpulkan bahwa sebagian besar responden atau 38 pengurus subak memiliki kategorisasi motivasi kerja dalam kategori yang tinggi.

Hal ini menunjukkan tinggi atau rendahnya motivasi kerja pengurus pengurus subak di Kecamatan Pekutatan dapat dijelaskan dari definisi operasional motivasi kerja. Motivasi kerja tinggi menunjukkan kemauan yang tinggi pengurus subak dalam mengerahkan kemampuannya untuk melakukan kegiatan yang menjadi tanggung jawabnya dalam rangka pencapaian tujuan organisasi. Selain itu, 8,62\% pengurus subak memiliki motivasi kerja dalam kategori yang sedang perlu ditingkatkan kembali.

Penelitian ini mempunyai keterbatasan-keterbatasan dalam pelaksanaannya. Sehingga, saran yang dapat diberikan oleh peneliti untuk penelitian selanjutnya, antara lain:

1. Untuk menghindari kesulitan dalam bertemu dengan responden pada penelitian selanjutnya, peneliti menyarankan untuk berdiskusi dengan petinggi desa/ kelian subak, untuk mengetahui jadwal kegiatan yang ada di Desa tempat subak tersebut berada.

2. Memperbesar cakupan populasi dan memperbesar sampel agar hasil penelitian lebih dapat digeneralisasikan dan dapat menggambarkan situasi dan kondisi pengurus subak yang sebenarnya di Bali.

3. Mengacu pada nilai koefisien determinasi penelitian ini yang sebesar 0,696 yang berarti bahwa sumbangan relatif yang diberikan oleh variabel rasa komunitas terhadap motivasi kerja yaitu sebesar 48,4 \%. dan selebihnya sebesar 51,6\% dipengaruhi oleh faktor lain yang tidak diteliti dalam penelitian ini. Maka disarankan kepada peneliti selanjutnya meneliti variabel-variabel lain yang mungkin dapat memiliki hubungan dengan motivasi kerja pengurus subak di Jembrana agar dapat lebih mengetahui faktor-faktor apa sajakah yang menjadi pendukung serta penghambat motivasi kerja pengurus subak.

4. Metode penelitian selanjutnya dapat menggunakan mix-method research yang menggabungkan penelitian kuantitatif dan kualitatif. Sehingga, hasil dari penelitian kuantitatif dapat dijelaskan secara lebih mendetail dengan penelitian kualitatif selanjutnya. Diharapkan hasil penelitian yang didapatkan dapat menjelaskan rasa komunitas dan motivasi kerja pengurus subak dalam mengelola subak tersebut.

5. Untuk penelitian selanjutnya menggunakan lebih dari 1 professional judgement untuk menaikkan validitas tampak penelitian ini dan aitem-aitem pada skala penelitian selanjutnya harus mengungkaplebih tajam terhadap aspekaspek yang diukur.

\section{DAFTAR PUSTAKA}

Alhbrant, R. S., \& Cunningham, J. V. (1979). A new public policy for neighborhood preservation. New York: Praeger.

Anoraga, P. (2005). Psikologi kerja. Jakarta: PT. Rineka Cipta.

Ambler, S. J. (1991). Irigasi di Indonesia : Dinamika kebudayaan petani. Jakarta: LP3ES.

American Psychology Association. (2002). APA ethical guidelines for research. Diakses pada tanggal 2 Desember 2012 dari www.sandplay.org/pdf/APA_Ethical_Guidelines_for_Research. pdf.

Arninda, E. D. P., \& Safitri, R. M. (2012). Hubungan antara kohesivitas kelompok dengan motivasi kerja pegawai kelurahan di Kecamatan Kasihan Kabupaten Bantul. Diakses pada tanggal 2 Desember 2012 dari

http://fpsi.mercubuana-yogya.ac.id/wpcontent/uploads/2012/06/Arninda-Ranni-MS-KohesivitasKelompok..ok_.pdf.

Asril. (2013). Kekurangan air, padi hasil panen sawah tadah hujan buruk. Diakses pada tanggal 2 Januari 2013 dari http://www.dnaberita.com/berita-82084-kekurangan-air-padihasil-panen-sawah-tadah-hujan-buruk.html.

Azwar, S. (2000). Penyusunan skala psikologi. Yogyakarta: Pustaka Pelajar.

Azwar, S. (2010). Reliabilitas dan validitas. Yogyakarta: Pustaka Pelajar.

Boediono W., \& Koster, W. (2004). Teori dan aplikasi statistika dan probabilitas. Bandung: PT Remaja Rosdakarya.

Dalton, J. H., Elias, M.J., \& Wandersman, A. (2001). Community psychology: Linking individuals and communities. Belmont: Wadsworth.

Donder. I. K. (2008). Subak: Konsep pertanian religius. Surabaya: Paramita.

Denny, R. (1992). Sukses memotivasi. Jakarta: PT. Gramedia.

Dewi, P. M. (2008). Motivasi kerja SPG (sales promotion girl) dalam menawarkan produk ditinjau dari konsep diri. Diakses pada tanggal 3 Desember 2012 dari http://eprints.unika.ac.id/2077/.

Farhan, A. Mengenal subak dan hijaunya sawah di Jatiluwih, Bali. Diakses pada tanggal 21 Agustus 2013 dari http://travel.detik.com/read/2012/05/21/140205/1920845/1025/ mengenal-subak-dan-hijaunya-sawah-di-jatiluwih-bali

Fransisca, E. D. (2006). Peran kepemimpinan dalam meningkatkan motivasi kerja pegawai Peranan kepemimpinan dalam meningkatkan motivasi kerja pegawai pada bagian kepegawaian PT. Samudera Indonesia Tbk, Cabang Medan. Diakses pada tanggal 2 Oktober 2012 dari http://repository.usu.ac.id/handle/123456789/11520

Gibson, J. L., dkk. (2003). Organizations: Behavior structure processes. New York: McGraw -Hill Irwin.

Hadi, A.P. (2001). Eksistensi desa adat dan kelembagaan lokal: Kasus Bali. Denpasar: Yayasan Agribisnis/Pusat Pengembangan Masyarakat Agrikarya (PPMA).

Hadi, S. (2000). Metodologi research. Yogjakarta: Andi. 
Hamzah, B. (2011). Teori Motivasi dan Pengukurannya: Analisis di bidang pendidikan. Jakarta: Bumi aksara.

Hassanudin. (2012, 10 Oktober). Tatkala Subak Kehilangan Sumber Air. Kompas. Diakses dari http://regional.kompas.com/read/2013/03/13/02383574/Tatkala. Subak.Kehilangan.Sumber.Air.

Hasibuan, S. P. M. (2007). Manajemen sumber daya manusia. Jakarta: Bumi Aksara.

Handayani, S. (2010). Buku ajar keluarga berencana. Yogyakarta: Pustaka Rihama

Hughey, J., dkk. (1999). Sense of community in community organizations: Structure and evidence of validity. Journal of Community Psychology, 27, 97-113.

Kenyon, D. C. (2007). Ethnic identity, sense of community, and psychological well-being among northern plains American Indian Youth. Journal of Community Psychology, 39, 1-9.

Komara, A. H. (2008). Hubungan antara motivasi kerja dan kinerja pegawai. Jurnal Jeroka Riau, 33, 36-42.

Mangkunegara, A. P. (2002). Manajemen sumber daya manusia perusahaan. Bandung : PT. Remaja Rosdakarya.

Martoyo, S. (2000). Manajemen Sumber Daya Manusia. Yogjakarta: BPFE.

McMillan, D. W., dan Chavis, D.M. (1986). Sense of community: A definition and theory. Journal of Community Psychology, 34, 315-326.

Gibson, J. L., dkk. (2003). Organizations: Behavior structure processes. New York: McGraw -Hill Irwin.

Hadi, A.P. (2001). Eksistensi desa adat dan kelembagaan lokal: Kasus Bali. Denpasar: Yayasan Agribisnis/Pusat Pengembangan Masyarakat Agrikarya (PPMA).

Hadi, S. (2000). Metodologi research. Yogjakarta: Andi.

Hamzah, B. (2011). Teori Motivasi dan Pengukurannya: Analisis di bidang pendidikan. Jakarta: Bumi aksara.

Hassanudin. (2012, 10 Oktober). Tatkala Subak Kehilangan Sumber Air. Kompas. Diakses dari http://regional.kompas.com/read/2013/03/13/02383574/Tatkala. Subak.Kehilangan.Sumber.Air.

Hasibuan, S. P. M. (2007). Manajemen sumber daya manusia. Jakarta: Bumi Aksara.

Handayani, S. (2010). Buku ajar keluarga berencana. Yogyakarta: Pustaka Rihama

Hughey, J., dkk. (1999). Sense of community in community organizations: Structure and evidence of validity. Journal of Community Psychology, 27, 97-113.

Kenyon, D. C. (2007). Ethnic identity, sense of community, and psychological well-being among northern plains American Indian Youth. Journal of Community Psychology, 39, 1-9.

Komara, A. H. (2008). Hubungan antara motivasi kerja dan kinerja pegawai. Jurnal Jeroka Riau, 33, 36-42.

Mangkunegara, A. P. (2002). Manajemen sumber daya manusia perusahaan. Bandung : PT. Remaja Rosdakarya.

Martoyo, S. (2000). Manajemen Sumber Daya Manusia. Yogjakarta: BPFE.

McMillan, D. W., dan Chavis, D.M. (1986). Sense of community: A definition and theory. Journal of Community Psychology, 34, 315-326. 